\title{
P70S6K Inhibitor LY2584702
}

National Cancer Institute

\section{Source}

National Cancer Institute. p70S6K Inhibitor LY2584702. NCI Thesaurus. Code C91393.

An orally available inhibitor of p7056K signaling, with potential antineoplastic activity. p70S6K inhibitor LY2584702 inhibits ribosomal protein S6 Kinase (p70S6K), and prevents phosphorylation of the $\mathbf{S} 6$ subunit of ribosomes, thereby inhibiting normal ribosomal function within tumor cells leading to a decrease in protein synthesis and in cellular proliferation. P70S6K, a serine/threonine kinase, acts downstream of PIP3 and phosphoinositide-dependent kinase-1 in the PI3 kinase pathway, is often upregulated in a variety of cancer cells, and is involved in the regulation of cell growth, proliferation, motility, and survival. 